\title{
Bioavailability of dissolved organic nitrogen and carbon from nine rivers in the eastern United States
}

\author{
Tracy N. Wiegner ${ }^{1,5, *}$, Sybil P. Seitzinger ${ }^{2}$, Patricia M. Glibert ${ }^{3}$, Deborah A. Bronk ${ }^{4,6}$ \\ ${ }^{1}$ Institute of Marine and Coastal Sciences, and ${ }^{2}$ NOAA CMER Program, Institute of Marine and Coastal Sciences, Rutgers, \\ The State University of New Jersey, 71 Dudley Road, New Brunswick, New Jersey 08901-8521, USA \\ ${ }^{3}$ Horn Point Laboratory, University of Maryland Center for Environmental Science, PO Box 755, Cambridge, \\ Maryland 21613, USA \\ ${ }^{4}$ Department of Marine Sciences, University of Georgia, 220 Marine Sciences Building, Athens, Georgia 30602-3636, USA \\ ${ }^{5}$ Present address: Marine Science Department, University of Hawaii at Hilo, 200 W. Kawili Street, Hilo, Hawaii 96720, USA \\ ${ }^{6}$ Present address: College of William and Mary/VIMS, Department of Physical Sciences, Route 1208, Greate Road, \\ Gloucester Point, Virginia 23062, USA
}

\begin{abstract}
Dissolved organic nitrogen (DON) and carbon (DOC) often dominate the dissolved nitrogen and organic carbon fluxes from rivers, yet they are not considered to affect coastal water quality because of their assumed refractory nature. The objective of this study was to quantify DON and DOC bioavailability to bacteria in 9 rivers on the east coast of the United States during a $6 \mathrm{~d}$ dark bioassay experiment. Water was collected from the freshwater portion of a forest stream in New Jersey (Forest 17a), and from the Bass (New Jersey), Delaware (New Jersey), Hudson (New York), Altamaha (Georgia), Savannah (Georgia), Pocomoke (Maryland), Choptank (Maryland), and Peconic (New York) Rivers during base-flow conditions. DON concentrations ranged from 1 to $35 \mu \mathrm{M}$ and comprised 8 to $94 \%$ of the total dissolved nitrogen (TDN) in these rivers. Bioassay results indicate that $23 \%( \pm 4)$ of the DON $(2 \pm 1 \mu \mathrm{M})$ was bioavailable in all the rivers except the Bass and Pocomoke, where no DON consumption was measured. Of the TDN consumed by bacteria, DON comprised $43 \%$ $( \pm 6)$, demonstrating that DON is an important nitrogen source for bacteria. In contrast, only $4 \%( \pm 1)$ of DOC $(12 \pm 3 \mu \mathrm{M})$, was bioavailable in the 9 rivers. Percent-wise, 8 times more DON was consumed relative to DOC in 6 of the rivers, demonstrating that DON cycles faster than DOC. Overall, our study demonstrates that DON is an important part of the TDN pool that needs to be incorporated into coastal nitrogen loading budgets because it is bioavailable on the order of days.
\end{abstract}

KEY WORDS: Bacteria $\cdot$ Bioavailability $\cdot$ DON $\cdot$ DOC $\cdot$ Rivers

Resale or republication not permitted without written consent of the publisher

\section{INTRODUCTION}

Nitrogen and carbon are important components of the dissolved organic matter (DOM) pool in rivers. Dissolved organic nitrogen (DON) can comprise up to $90 \%$ of both the total dissolved nitrogen (TDN) concentration in and export from some rivers (e.g. Seitzinger \& Sanders 1997). Similarly, dissolved organic carbon (DOC) is often the largest riverine organic carbon pool (e.g. Schlesinger \& Melack 1981). Historically, riverine DOM was considered refractory because of its high $\mathrm{C}: \mathrm{N}$ ratio, reported conservative mixing in some estuaries, and predominance of humic substances that were previously considered to be biologically unavailable (Mantoura \& Woodward 1983, Thurman 1985). However, recent studies have shown that riverine DOM is metabolically important in rivers and estuaries; it supplies energy (carbon) and nutrients (nitrogen) to bacteria and some algae (Servais et al. 1987, Stepanauskas et al. 1999a, Wikner et al. 1999, Glibert et al. 2001, See et al. 2006), potentially contributing to coastal eutrophication and hypoxia (Seitzinger \& Sanders 1997, Paerl et al. 1998, Glibert et al. 2006). 
Bioavailability of DOM in rivers is largely affected by the chemical composition of the DOM pool (Sun et al. 1997). Chemical composition of this pool is determined by the sources of DOM to the river. Riverine DOM can originate from numerous natural and anthropogenic watershed sources, atmospheric deposition, and autochthonous production. DOM bioavailability has been shown to vary with DOM source (Seitzinger et al. 2002). For example, DOM in rain, suburban/urban runoff, and released from autochthonous production is very bioavailable to bacteria and some algae (Bronk \& Glibert 1993, Seitzinger \& Sanders 1999, Glibert et al. 2001, Seitzinger et al. 2002), whereas DOM from forests, wetlands, and agricultural soils is less bioavailable (reviewed in Wiegner \& Seitzinger 2004). Hence, the relative contribution of DOM from these sources will affect how much of the DOM in rivers is bioavailable.

Riverine DOM bioavailability is also affected by chemical, biological, and physical processes of the terrestrial landscape, as well as of the river. Microbial consumption, sorption to soil particles, and hydrological transport pathways can alter the chemical composition of DOM entering rivers (reviewed in AitkenheadPeterson et al. 2003). Photochemical reactions and flocculation can further modify the chemical composition of DOM within rivers (e.g. Moran et al. 1999, Auf-

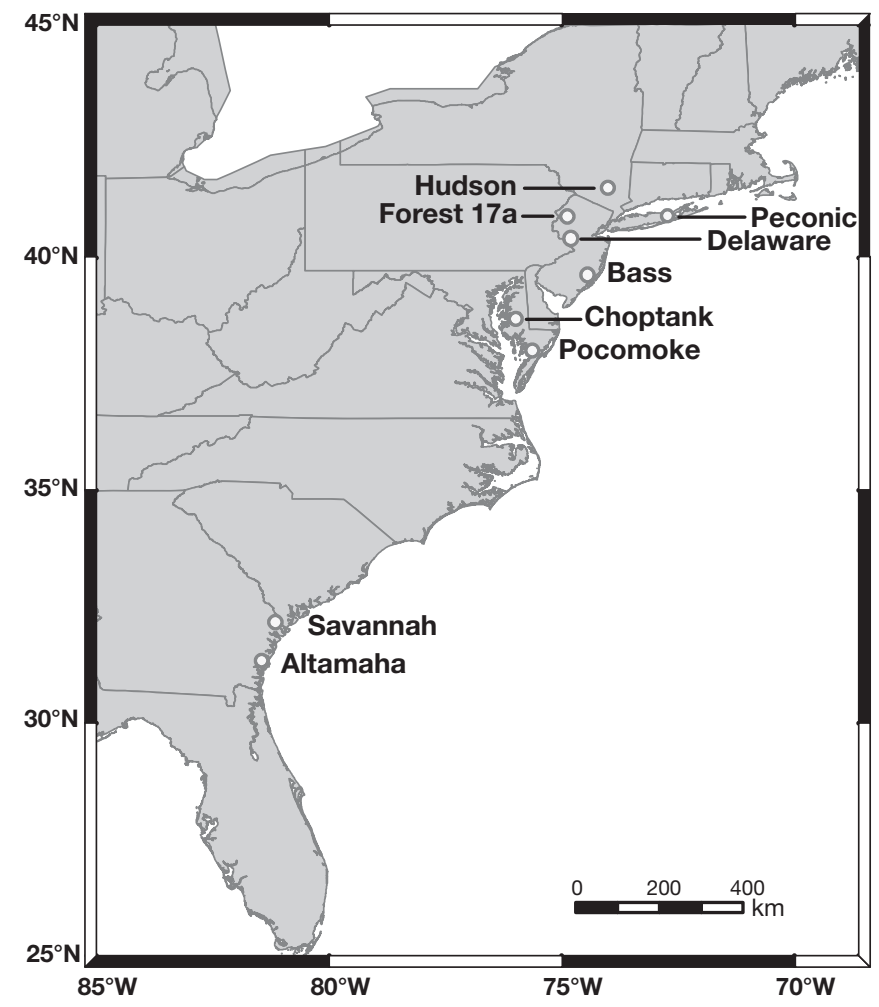

Fig. 1. Map of the 9 river locations, on the east coast of the United States, where dissolved organic matter (DOM) bioavailability was studied denkampe et al. 2001, Kerner et al. 2003). However, the relative importance of these processes in altering the chemical composition and bioavailability of riverine DOM are not well known (Findlay \& Sinsabaugh 1999).

DOC bioavailability has been extensively examined in rivers (reviewed in del Giorgio \& Davis 2003). Less is known about DON bioavailability in rivers, and few studies have examined DON and DOC bioavailability simultaneously (Stepanauskas et al. 2000, Wiegner \& Seitzinger 2001, 2004). While few in number, these studies have shown that the consumption and fate of DON and DOC within the aquatic bacterial community differ (Stepanauskas et al. 2000, Wiegner \& Seitzinger 2001, 2004). These findings have implications for the quantity and quality of DOM exported from rivers to estuaries and the role of this material in freshwater and estuarine food webs. In the present paper, the bioavailability of riverine DON and DOC from 9 rivers along the east coast of the United States was examined through a dark bioassay experiment. The goals of this study were to: (1) evaluate DOM bioavailability in rivers with different land covers (DOM sources), (2) compare utilization of DON and DOC by bacteria, and (3) assess the importance of DON as a nitrogen source to bacteria.

\section{MATERIALS AND METHODS}

Study sites. The bioavailability of DOM to freshwater bacteria was examined in 9 rivers along the east coast of the United States: a first order forest stream in New Jersey (Forest 17a), and the East Branch Bass (hereafter referred to as Bass; New Jersey), Delaware (New Jersey), Hudson (New York), Altamaha (Georgia), Savannah (Georgia), Pocomoke (Maryland), Choptank (Maryland), and Peconic (New York) Rivers (Fig. 1). Water was collected from the freshwater portion of these rivers in the summer (July and August) of 1998 during base-flow conditions. Forest $17 \mathrm{a}$ and the Bass River have the most natural watersheds, with forests and wetlands comprising $>95 \%$ of their land cover (Table 1). The Delaware, Hudson, Altamaha, and Savannah watersheds have mixed land-cover distributions dominated by forests (Table 1). The watersheds of the Pocomoke and Choptank Rivers are dominated by agriculture, while urban areas dominate the Peconic River watershed (Table 1).

River water was collected into either 101 cubitainers or several 11 plastic bottles, rinsed several times with river water before sampling. Water samples were filtered through either a $0.5 \mu \mathrm{m}$ string-wound polypropylene canister filter on-site or through a glass fiber filter (Whatman GF/F) in the laboratory. All samples 
were stored on ice during transport to the laboratory, where they were stored frozen for up to 1 mo prior to the bioassay experiment. Plastics and glassware used in this work were acid-cleaned; glassware and GF/F filters were combusted at $500^{\circ} \mathrm{C}$ to render them carbon-free. Filters were rinsed with deionized water (DIW) prior to sample filtering.

Experimental design. Riverine DOM bioavailability was examined by adding freshwater bacteria to sterile filtered water (river and DIW control) and then monitoring nutrient concentrations daily for $6 \mathrm{~d}$ (Seitzinger \& Sanders 1997, Wiegner \& Seitzinger 2001). This length of time encompasses the period in which DOM is processed in rivers prior to entering the estuary. A day prior to the experiment, river and control waters were thawed, sterile filtered through $0.2 \mu \mathrm{m}$ polycarbonate membrane filters (Gelman Sciences Supor200), and stored overnight in the dark at $4^{\circ} \mathrm{C}$. Water for the bacterial inoculum was also collected and prepared on this day. A single freshwater bacterial inoculum was used to facilitate DOM bioavailability comparisons across rivers. Water for the bacterial inoculum was collected from Weston Mill Pond, New Jersey $\left(40^{\circ} 28^{\prime} 59^{\prime \prime} \mathrm{N}, 74^{\circ} 24^{\prime} 47^{\prime \prime} \mathrm{W}\right)$. DOM bioavailability estimates are likely conservative, because bacteria within the inoculum were not preconditioned to the various DOM molecules within the different rivers examined. Water for the bacterial inoculum was filtered through a $0.5 \mu \mathrm{m}$ string-wound polypropylene canister filter to remove large particles. The inoculum was prepared by filtering $1 \mathrm{l}$ of pond water through a GF/F filter, pulse sonicating it to remove remaining protists, and stored overnight at $4^{\circ} \mathrm{C}$ (Seitzinger \& Sanders 1997).

On Day 1 of the experiment, $20 \mathrm{ml}$ of the bacterial inoculum was added to 21 of the sterile, filtered river and control waters. The inoculated waters were mixed well and then divided evenly into duplicate 21 Erlenmeyer flasks. Flasks were covered with aluminum foil, gently stirred with Teflon-coated stir bars, and incubated in the dark at $25^{\circ} \mathrm{C}$ for $6 \mathrm{~d}$. Initial and daily timeseries nutrient samples for ammonium $\left(\mathrm{NH}_{4}{ }^{+}\right)$, nitrate plus nitrite $\left(\mathrm{NO}_{3}{ }^{-}+\mathrm{NO}_{2}{ }^{-}\right)$, phosphate $\left(\mathrm{PO}_{4}{ }^{3-}\right)$, TDN, and DOC were taken over the course of the experiment. Samples for urea and dissolved organic phosphorus (DOP) were taken from the river waters prior to bacterial inoculation. Waters for these analyses were

Table 1. Location and physical characteristics of river sites and their watersheds. NA: data not available

\begin{tabular}{|c|c|c|c|c|c|c|c|c|c|}
\hline River & Lat. & Long. & $\begin{array}{l}\text { Drainage area } \\
\qquad\left(\mathrm{km}^{2}\right)\end{array}$ & $\begin{array}{l}\text { Population } \\
\text { density } \\
\text { (ind. } \mathrm{km}^{-2} \text { ) }\end{array}$ & $\%$ Urban & $\%$ Agriculture & $\%$ Forest & \%Wetland & $\%$ Other \\
\hline Forest $17 \mathrm{a}^{\mathrm{a}}$ & $40^{\circ} 48^{\prime} 52^{\prime \prime} \mathrm{N}$ & $74^{\circ} 58^{\prime} 05^{\prime \prime} \mathrm{W}$ & $0.46^{\mathrm{a}}$ & & 0 & 0 & & 0 & 0 \\
\hline Bass $^{b}$ & ' 37 ' 42 " N & $74^{\circ} 26^{\prime} 45^{\prime \prime} \mathrm{W}$ & & & 2.03 & 0 & 82 & 14.04 & 1.23 \\
\hline Delaware $^{\mathrm{c}}$ & $40^{\circ} 24^{\prime} 46^{\prime \prime} \mathrm{N}$ & $74^{\circ} 56^{\prime} 75^{\prime \prime} \mathrm{W}$ & 17581 & 73.7 & 3.3 & 16.5 & 74.6 & 2.5 & 3 \\
\hline Hudson $^{\mathrm{d}}$ & ${ }^{\circ} 30^{\prime} 15^{\prime \prime} \mathrm{N}$ & $74^{\circ} 00^{\prime} 22^{\prime \prime} \mathrm{W}$ & 4 & 60.4 & 6.16 & 19.89 & 64.43 & NA & 9.42 \\
\hline Altamaha ${ }^{\mathrm{d}, \mathrm{e}}$ & $31^{\circ} 19^{\prime} 93^{\prime \prime} \mathrm{N}$ & $81^{\circ} 26^{\prime} 54^{\prime \prime} \mathrm{W}$ & $36260^{\mathrm{d}}$ & $49.6^{\mathrm{d}}$ & $3.3^{\mathrm{e}}$ & $26.4^{\mathrm{e}}$ & 64. & $4.8^{\mathrm{e}}$ & $1.3^{\mathrm{e}}$ \\
\hline Savannah $^{\mathrm{d}}$ & $32^{\circ} 09^{\prime} 63^{\prime \prime} \mathrm{N}$ & $81^{\circ} 09^{\prime} 31^{\prime \prime} \mathrm{W}$ & 2 & 34.9 & 5.42 & 25.0 & 52.28 & NA & 17.28 \\
\hline Pocomoke $^{f}$ & $38^{\circ} 00^{\prime} 40^{\prime \prime} \mathrm{N}$ & $75^{\circ} 37^{\prime} 64^{\prime \prime} \mathrm{W}$ & & 17.7 & & & 1 & 17.3 & 0.5 \\
\hline Choptank $^{\mathrm{f}}$ & $38^{\circ} 41^{\prime} 22^{\prime \prime} \mathrm{N}$ & $75^{\circ} 58^{\prime} 61^{\prime \prime} \mathrm{W}$ & 917 & & & & 26 & 14.4 & 2.4 \\
\hline Peconic $^{\mathrm{d}}$ & $40^{\circ} 54^{\prime} 20^{\prime \prime} \mathrm{N}$ & $72^{\circ} 44^{\prime} 37^{\prime \prime} \mathrm{W}$ & 194 & & 33.33 & & & NA & 37.5 \\
\hline \multicolumn{10}{|c|}{$\begin{array}{l}{ }^{\mathrm{a}} \text { C. Dow (pers. comm.). Drainage area was calculated using Arc View } 8.2 \text { software } \\
{ }^{b} \text { R. Zampella (pers. comm.). Land use/land-cover profiles were prepared using Arc View 3.X software, Environmental Sys- } \\
\text { tems Research Institute; } 1988 \text { to } 1992 \text { digital land use/land-cover data were obtained from New Jersey Department of Envi- } \\
\text { ronmental Protection (NJDEP) (1991/1997 land use/land-cover update 2001). Drainage basin boundaries were prepared } \\
\text { using Arc View software, and digital hydrography data were obtained from NJDEP (1996 NJ GIS CD-ROM Series 1, Volumes } \\
1 \text { to 4). \%Other includes barren land and water cover }\end{array}$} \\
\hline \multicolumn{10}{|c|}{$\begin{array}{l}\text { 'J. Fischer (pers. comm.). Land use derived from Landsat thematic data } 1991 \text { to 1993. Population data from US Census } 1990 . \\
\text { Data are for the Delaware River near Trenton, New Jersey (40¹3'18" N, } 74^{\circ} 46^{\prime} 42^{\prime \prime} \text { W) }\end{array}$} \\
\hline \multicolumn{10}{|c|}{$\begin{array}{l}\text { 'Data from USGS National Water Quality Network CD-ROM; population density is from US Census } 1990 \text {. Land use is from } \\
\text { 1987. \%Agriculture is the sum of land in crop, pasture, and farmland. Data are for the Hudson River near Poughkeepsie, New } \\
\text { York }\left(41^{\circ} 43^{\prime} 18^{\prime \prime} \mathrm{N}, 73^{\circ} 56^{\prime} 28^{\prime \prime} \mathrm{W}\right) \text {, the Altamaha River at Everett City, Georgia }\left(31^{\circ} 25^{\prime} 37^{\prime \prime} \mathrm{N}, 81^{\circ} 36^{\prime} 20^{\prime \prime} \text { W), the Savannah }\right. \\
\text { River near Clyo, Georgia }\left(32^{\circ} 31^{\prime} 30^{\prime \prime} \mathrm{N}, 81^{\circ} 15^{\prime} 45^{\prime \prime} \mathrm{W}\right) \text {, and the Peconic River at Riverhead, New York }\left(40^{\circ} 45^{\prime} 49^{\prime \prime} \mathrm{N} \text {, }\right. \\
\left.72^{\circ} 41^{\prime} 14^{\prime \prime} \mathrm{W}\right)\end{array}$} \\
\hline \multicolumn{10}{|c|}{$\begin{array}{l}\text { 'Data from USGS Water-Resources Investigations Report 97-4006 (Asbury \& Oaksford 1997). Residential, commericial, indus- } \\
\text { trial, and other urban areas were combined into urban category. Data are for the Altamaha River at Everett City, Georgia } \\
\left(31^{\circ} 25^{\prime} 37^{\prime \prime} \mathrm{N}, 81^{\circ} 36^{\prime} 20^{\prime \prime} \mathrm{W}\right)\end{array}$} \\
\hline \multicolumn{10}{|c|}{$\begin{array}{l}{ }^{\mathrm{f}} \text { Data from } 1991 \text { to } 1993 \text { LandSat Imagery from the Multi-Resolution Land Characteristic Consortium (MRLC). Land-cover } \\
\text { data compiled by Chesapeake Bay Program Office. Developed areas are treated as urban category. \% Other includes barren } \\
\text { and water category. Population data are from US Census 1990. Data are for the upper Pocomoke and Choptank Rivers. Infor- } \\
\text { mation was obtained at http://maps.chesapeakebay.net }\end{array}$} \\
\hline
\end{tabular}




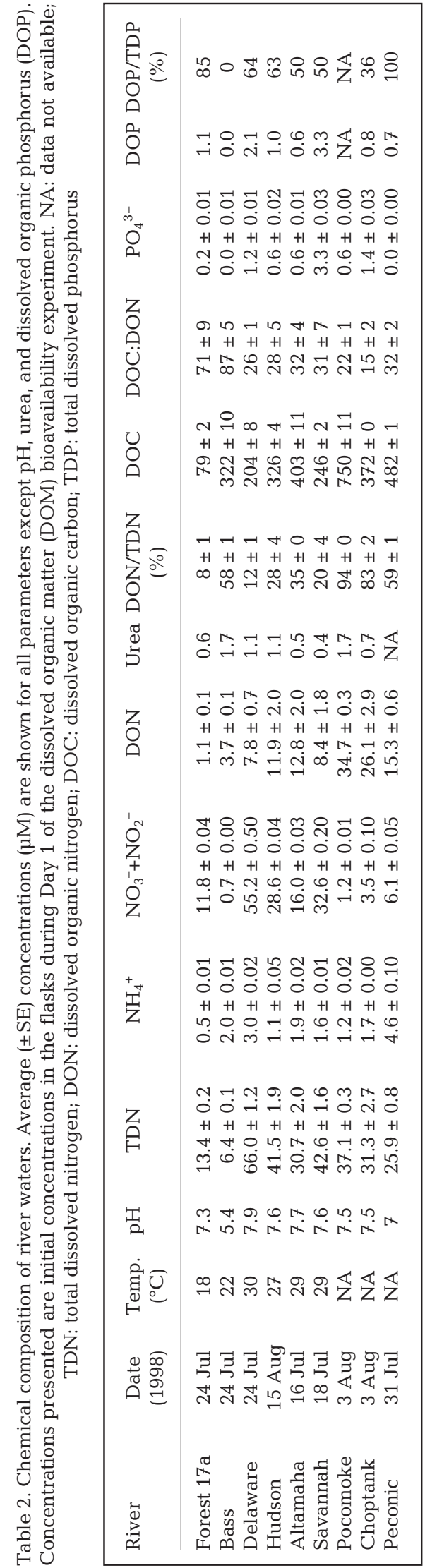

filtered through GF/F filters and stored frozen until analysis. The amount of DOM consumed during the experiment was calculated from initial and final DON and DOC concentrations in the duplicate flasks. DOM bioavailability is expressed as percent DOM utilization (amount DOM consumed/amount DOM initially present $\times 100$ )

Analytical measurements. Concentrations of $\mathrm{NH}_{4}{ }^{+}$ (Lachat QuickChem 31-107-06-1-A), $\mathrm{NO}_{3}{ }^{-}+\mathrm{NO}_{2}{ }^{-}$ (Lachat QuickChem Method 31-107-04-1-A), and $\mathrm{PO}_{4}{ }^{3-}$ (Lachat QuickChem Method 31-115-01-3-A) were measured using standard autoanalyzer methods. TDN was analyzed by high-temperature combustion, followed by chemiluminescent detection of nitric oxide using an Antek Model 7000 Total N Analyzer (Antek) equipped with a quartz combustion tube $\left(1000 \pm 10^{\circ} \mathrm{C}\right)$ and a ceramic insert (Seitzinger \& Sanders 1997). TDN samples were preserved in capped autosampler vials with $3 \mathrm{~N} \mathrm{HCl}$ ( $7.5 \mu \mathrm{l}$ acid per $1.5 \mathrm{ml}$ sample). Both dissolved inorganic $\left(\mathrm{NH}_{4}{ }^{+}\right.$and $\left.\mathrm{NO}_{3}{ }^{-}+\mathrm{NO}_{2}^{-} ; \mathrm{DIN}\right)$ and organic (urea) nitrogen standards for TDN analysis were prepared in DIW. DON was determined from the difference between TDN and DIN. Urea was analyzed using the diacetyl monoxime method (Price \& Harrison 1987). DOC was measured by high-temperature combustion (Shimadzu TOC-5000A, Sharp et al. 1993). DOP was measured using persulfate oxidation according to Valderrama (1981).

Statistical analyses. For statistical analysis, duplicate flasks for each river were treated as individual observations. Differences in DOM bioavailability were examined by 1-way analysis of variance (ANOVA; Systat 8.0 software). Log and rank transformations were performed on data sets to satisfy the normality and equality of variance requirements for ANOVA (Potvin \& Roff 1993). Post-hoc analyses were performed using Tukey's Studentized range test.

\section{RESULTS}

\section{River water composition}

TDN concentrations ranged from 6 to $66 \mu \mathrm{M}$ and were lowest in the Bass River and highest in the Delaware (Table 2). DON comprised 8 to $94 \%$ of the TDN in the sampled rivers, with urea constituting 3 to $55 \%$ of the DON (calculated from Table 2). DIN concentrations ranged from 2 to $58 \mu \mathrm{M}$, with $\mathrm{NO}_{3}{ }^{-}+\mathrm{NO}_{2}{ }^{-}$ and $\mathrm{NH}_{4}{ }^{+}$comprising $75 \%( \pm 6$; average $\pm \mathrm{SE})$ and $25 \%$ $( \pm 5)$ of the DIN in the rivers, respectively (calculated from Table 2). Concentrations of DOC ranged from 79 to $750 \mu \mathrm{M}$ and were lowest in Forest $17 \mathrm{a}$ and highest in the Pocomoke River (Table 2). The DOC:DON ratio in the rivers ranged from 15 to 87 and was the lowest 
in the Choptank and the highest in the Bass River (Table 2). The ranges in DOP and $\mathrm{PO}_{4}{ }^{3-}$ concentrations $(\leq 0.1$ to $3.3 \mu \mathrm{M}$ ) were similar; the Bass had the lowest concentrations for both constituents, while the Savannah River had the highest (Table 2). DOP comprised at least $50 \%$ of the total dissolved phosphorus (TDP) in most rivers, except in the Choptank and Bass (Table 2).

\section{DOM bioavailability experiment}

Bacteria readily consumed DON in all the rivers except in Bass and Pocomoke (Fig. 2). With the exception of these 2 rivers, a similar absolute amount $(2 \pm 1$ $\mu \mathrm{M} ; \mathrm{p}=0.22)$ and percent of DON $(23 \pm 4 \% ; \mathrm{p}=0.44)$ was consumed during the $6 \mathrm{~d}$ experiment, irrespective of the initial DON concentrations (Fig. 2, Tables $2 \& 3$ ). DON comprised a similar percentage $(43 \pm 6 \% ; \mathrm{p}=$ 0.60 ) of the TDN consumed by the bacteria across rivers (Fig. 3). Likewise, a similar absolute amount $\left(12 \pm 3 \mu \mathrm{M}_{i} \mathrm{p}=0.127\right)$ and percent of DOC $(4 \pm 1 \% ; \mathrm{p}=$ 0.20 ) was consumed in the rivers, regardless of the initial DOC concentrations (Fig. 2, Tables 2 \& 3).

Small changes in DIN and $\mathrm{PO}_{4}{ }^{3-}$ concentrations were observed during the $6 \mathrm{~d}$ experiment in most rivers (Table 4). There was generally a small net consumption of $\mathrm{NH}_{4}{ }^{+}$in most rivers; however, in the Hudson River, a small amount of $\mathrm{NH}_{4}{ }^{+}$was produced (Table 4). Both $\mathrm{NO}_{3}{ }^{-}+\mathrm{NO}_{2}{ }^{-}$consumption and production were observed in the rivers (Table 4). Small quantities of $\mathrm{PO}_{4}{ }^{3-}$ were consumed at most sites; however, in Forest $17 \mathrm{a}$ and the Bass and Peconic Rivers, there was either no net change or a small increase in the $\mathrm{PO}_{4}{ }^{3-}$ concentration (Table 4).

\section{DISCUSSION}

\section{Riverine DOM bioavailability}

The importance of DOM as a nutrient and energy source to riverine bacteria is becoming widely recognized (e.g. Servais et al. 1987, Seitzinger \& Sanders 1997). Across rivers, DON and DOC bioavailability varies widely ( 0 to $72 \%$ ) and averages $30 \%( \pm 4)$ and $25 \%( \pm 2)$, respectively (Table 5 ). In our study, the absolute amount and percent of DON consumed were similar among 7 of the rivers (Table 3 ). On average at these rivers, $2 \mu \mathrm{M}( \pm 1)$ of DON was consumed, which was equivalent to $23 \%( \pm 4)$ of the DON (Fig. 2, Table 3). Our values are comparable to previous DON bioavailability measurements in rivers (Table 5A). Likewise, a similar absolute amount and percent of DOC was consumed in the 9 rivers examined (Table 3). The average DOC bioavailability among rivers was

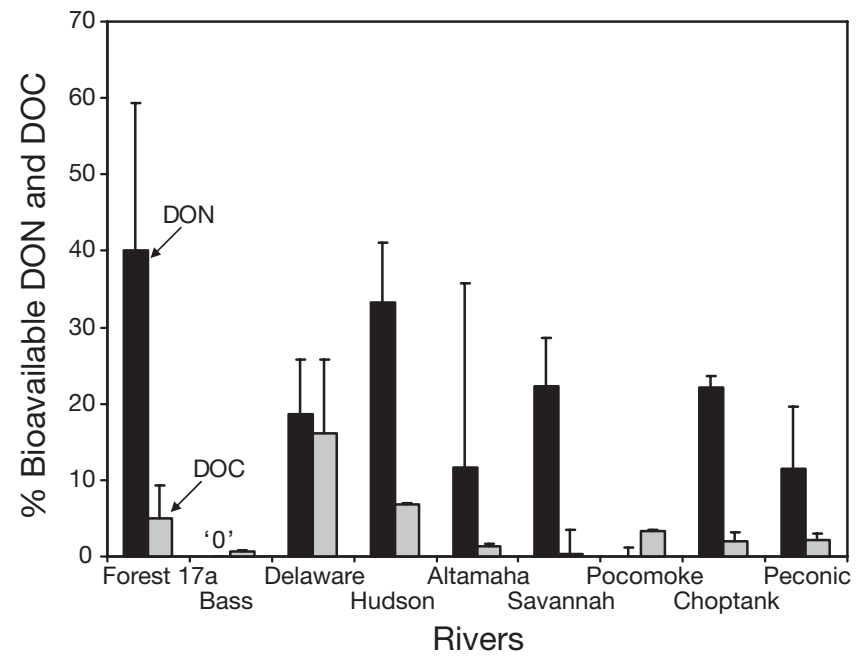

Fig. 2. Bioavailability of riverine dissolved organic nitrogen (DON) and carbon (DOC) reported as a percent of the initial DON and DOC concentration utilized after $6 \mathrm{~d}$. Averages $( \pm \mathrm{SE})$ for duplicate flasks are shown

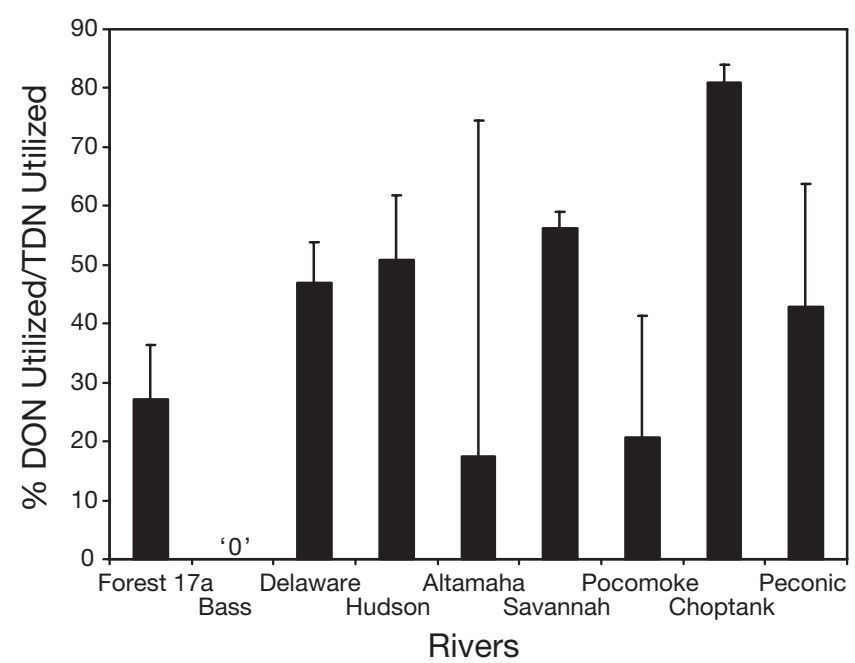

Fig. 3. Percent of total dissolved nitrogen (TDN) utilized by bacteria that was DON during the $6 \mathrm{~d}$ dissolved organic matter (DOM) bioavailability experiment. Little to no DON was utilized in the Bass River. Averages $( \pm \mathrm{SE})$ for duplicate flasks are shown

$4 \%( \pm 1)$, with $12 \mu \mathrm{M}( \pm 3)$ consumed (Fig. 2, Table 3). This value falls within the reported range of riverine DOC bioavailability, but is lower than the average across rivers (Table 5B). Longer bioassays, as well as differences in DOC chemical composition, may have contributed to the higher DOC bioavailability measured in earlier studies (Table 5B).

DOM consumption by bacteria can be affected by numerous factors, including temperature, light intensity/spectral distribution, nutrient availability, bacterial community composition, DOM chemical com- 
Table 3. Bacterial utilization of riverine DON and DOC during the DOM bioavailability experiment. Averages ( \pm SE) for duplicate flasks are shown. DOM bioavailability was calculated as the percent difference between initial and final DOM concentrations in the duplicate flasks. Initial concentrations for Day 1 of the DOM bioavailability experiment can be found in Table 2

\begin{tabular}{|c|c|c|c|c|c|}
\hline River & $\begin{array}{c}\text { Amount of } \\
\text { DON used }(\mu \mathrm{M})\end{array}$ & $\begin{array}{l}\% \text { DON } \\
\text { used }\end{array}$ & $\begin{array}{c}\text { Amount of } \\
\text { DOC used }(\mu \mathrm{M})\end{array}$ & $\begin{array}{c}\% \text { DOC } \\
\text { used }\end{array}$ & $\begin{array}{c}\text { Final } \\
\text { DOC:DON }\end{array}$ \\
\hline Forest $17 a$ & $0.5 \pm 0.3$ & $40 \pm 19$ & $4 \pm 3$ & $5 \pm 4$ & $120 \pm 20$ \\
\hline Bass & $0.0 \pm 0.0$ & $0 \pm 0$ & $2 \pm 1$ & $1 \pm 0$ & $67 \pm 5$ \\
\hline Delaware & $1.5 \pm 0.7$ & $19 \pm 7$ & $34 \pm 21$ & $16 \pm 10$ & $27 \pm 2$ \\
\hline Hudson & $4.1 \pm 1.6$ & $33 \pm 8$ & $22 \pm 1$ & $7 \pm 0$ & $39 \pm 2$ \\
\hline Altamaha & $2.0 \pm 3.3$ & $12 \pm 24$ & $5 \pm 1$ & $1 \pm 0$ & $37 \pm 6$ \\
\hline Savannah & $1.8 \pm 0.1$ & $22 \pm 6$ & $1 \pm 8$ & $1 \pm 3$ & $40 \pm 10$ \\
\hline Pocomoke & $0.0 \pm 0.4$ & $0 \pm 1$ & $25 \pm 1$ & $3 \pm 0$ & $26 \pm 0$ \\
\hline Choptank & $5.7 \pm 0.2$ & $22 \pm 2$ & $8 \pm 4$ & $2 \pm 1$ & $18 \pm 2$ \\
\hline Peconic & $1.7 \pm 1.2$ & $12 \pm 8$ & $10 \pm 4$ & $2 \pm 1$ & $35 \pm 5$ \\
\hline
\end{tabular}

position, and length of experiments (reviewed in del Giorgio \& Davis 2003). In our experiment, river waters were incubated for the same length of time, at the same temperature, in the dark, with the same initial bacterial community. Thus, comparable DOM bioavailability among rivers most likely resulted from: (1) some nutrient limiting DOM consumption and/or (2) similar chemical composition of the bioavailable DOM among rivers.

In our experiment, neither the amount of DON nor DOC consumed was significantly correlated to either initial DIN or $\mathrm{PO}_{4}{ }^{3-}$ concentrations $\left(\mathrm{r}^{2} \leq 0.31\right)$. These results suggest that the chemical composition of the riverine DOM affected its consumption by bacteria, not inorganic nutrient availability.

Similar DON and DOC bioavailability among the rivers examined here suggests that the chemical composition of the bioavailable DOM in these rivers was comparable. Chemical composition of riverine DOM is affected by the sources and flow paths of DOM to rivers, as well as by processes within rivers that can

Table 4. Net utilization (-) and production (+) of DIN and $\mathrm{PO}_{4}{ }^{3-}(\mu \mathrm{M})$ during the DOM bioavailability experiment. Averages $( \pm \mathrm{SE})$ for duplicate flasks are shown. Net changes were calculated from initial and final concentrations in the duplicate flasks. Initial concentrations for Day 1 of the DOM bioavailability experiment can be found in Table 2

\begin{tabular}{|lcrr|}
\hline River & $\begin{array}{c}\text { Net change } \\
\text { in } \mathrm{NH}_{4}{ }^{+}\end{array}$ & $\begin{array}{r}\text { Net change } \\
\text { in } \mathrm{NO}_{3}{ }^{-}+\mathrm{NO}_{2}{ }^{-}\end{array}$ & \multicolumn{1}{c|}{$\begin{array}{c}\text { Net change } \\
\text { in } \mathrm{PO}_{4}{ }^{3-}\end{array}$} \\
\hline Forest $17 \mathrm{a}$ & $-0.22 \pm 0.02$ & $-0.91 \pm 0.15$ & $0.05 \pm 0.18$ \\
Bass & $-0.19 \pm 0.02$ & $0.04 \pm 0.01$ & $0.00 \pm 0.00$ \\
Delaware & $-2.24 \pm 0.05$ & $0.68 \pm 0.38$ & $-0.22 \pm 0.02$ \\
Hudson & $0.23 \pm 0.2$ & $-3.90 \pm 0.10$ & $-0.22 \pm 0.03$ \\
Altamaha & $-1.53 \pm 0.02$ & $-1.78 \pm 1.52$ & $-0.20 \pm 0.08$ \\
Savannah & $-1.60 \pm 0.01$ & $0.20 \pm 0.27$ & $-0.12 \pm 0.03$ \\
Pocomoke & $-0.43 \pm 0.09$ & $-0.08 \pm 0.05$ & $-0.04 \pm 0.00$ \\
Choptank & $-1.06 \pm 0.24$ & $-0.28 \pm 0.44$ & $-0.19 \pm 0.01$ \\
Peconic & $-1.88 \pm 0.05$ & $0.10 \pm 0.09$ & $0.00 \pm 0.00$ \\
\hline
\end{tabular}

alter it. Sources of DOM to rivers include terrestrial and atmospheric inputs, as well as autochthonous production. Previous studies have shown that riverine DOM is primarily of terrestrial origin and that watershed land cover is a good predictor of riverine TDN, DIN, and TOC loads (e.g. Howarth et al. 1991, 1996, Peierls et al. 1991, Kaplan \& Newbold 1993, Palmer et al. 2001). Forest and agriculture are the dominant $(>77 \%)$ land covers in the rivers examined here (except the Peconic). The bioavailability of DON and DOC in runoff from these land covers are similar (Table 6) and within the range measured in the rivers examined. Additionally, DOM from forest and agriculture runoff is generally not affected by photochemical reactions (Wiegner \& Seitzinger 2001). Our results suggest that the similarity in DOM bioavailability among the rivers examined may, in part, be a result of watershed land cover.

Water flow paths from the terrestrial to the aquatic environment can also affect DOM chemical composition (Findlay et al. 2001, Sobczak \& Findlay 2002). In our study, water samples were collected during baseflow conditions, when transport of DOM to rivers is primarily through deeper groundwater and soil horizons (Hornberger et al. 1994, Boyer et al. 1996). Previous work has shown that the quantity and bioavailability of DOC in groundwater from different land covers are similar (Findlay et al. 2001, Sobczak \& Findlay 2002); the same may also be true for DON.

A combination of both watershed land cover and water flow paths most likely affected DOM bioavailability in these rivers. Given the design and chemical techniques used in our study, it is difficult to determine the relative contribution of each of the above factors in affecting riverine DOM bioavailability. Further research is needed to pinpoint which molecules in the riverine DOM pool are bioavailable and determine whether these molecules are similar across rivers and related to specific DOM sources, water flow paths, 
or processes. New techniques like electrosprayionization mass spectrometry show promise in providing the detailed molecular analysis needed for examining DOM dynamics. A recent study demonstrated that similar DOM masses from rivers with comparable land covers were consumed by bacteria during bioassay experiments (Seitzinger et al. 2005). The next research step would be to determine if these DOM masses comprise the bioavailable DOM in rivers with different land-cover types.

\section{DON versus DOC utilization}

The nitrogen and carbon components of the DOM pool appear to cycle differently through the bacterial community. In 6 out of 9 rivers studied here, percentwise, 8 times more DON was consumed than DOC (Fig. 2). These results suggest that the nitrogen-rich components of the DOM pool were preferentially utilized (Sun et al. 1997). There are 2 possible ways this could occur: (1) bacteria could selectively cleave nitro-

Table 5. Riverine (A) DON and (B) DOC bioavailability. Overall averages $( \pm \mathrm{SE})$ were calculated using original data from papers. NA: data not available

\begin{tabular}{|c|c|c|c|c|}
\hline Site & DOM conc. $(\mu \mathrm{M})$ & Experiment length (d) & $\%$ DOM used & Source \\
\hline \multicolumn{5}{|l|}{ (A) $\mathrm{DON}$} \\
\hline \multicolumn{5}{|l|}{ United States } \\
\hline Delaware & $13-47$ & $8-15$ & $40-72$ & Seitzinger \& Sanders (1997) \\
\hline Hudson & 34 & 10 & 40 & Seitzinger \& Sanders (1997) \\
\hline \multicolumn{5}{|l|}{ Sweden } \\
\hline Lillån & $26-36$ & 14 & $19-55$ & Stepanauskas et al. (2000) \\
\hline Stridbäcken & $17-20$ & 14 & $28-45$ & Stepanauskas et al. (2000) \\
\hline Amböke & $12-74$ & $6-14$ & $0-6$ & Stepanauskas et al. $(1999 a, b)$ \\
\hline Torne älv & 11 & 14 & 14 & Stepanauskas et al. (2002) \\
\hline Kalix älv & 11 & 14 & 67 & Stepanauskas et al. (2002) \\
\hline Lule älv & 20 & 14 & 39 & Stepanauskas et al. (2002) \\
\hline Alterälven & 23 & 14 & 29 & Stepanauskas et al. (2002) \\
\hline \multicolumn{5}{|l|}{ Finland } \\
\hline Pernonjoki & 37 & 14 & 41 & Stepanauskas et al. (2002) \\
\hline Siikajoki & 33 & 14 & 10 & Stepanauskas et al. (2002) \\
\hline Oulujoki & 19 & 14 & 8 & Stepanauskas et al. (2002) \\
\hline Liijoki & 31 & 14 & 14 & Stepanauskas et al. (2002) \\
\hline Simokoki & 42 & 14 & 8 & Stepanauskas et al. (2002) \\
\hline Kemijoki & 16 & 14 & 9 & Stepanauskas et al. (2002) \\
\hline \multicolumn{5}{|l|}{ Other countries } \\
\hline Nemunas, Lithuania & 37 & 14 & 47 & Stepanauskas et al. (2002) \\
\hline Salaca, Latvia & 53 & 14 & 51 & Stepanauskas et al. (2002) \\
\hline Kasari, Estonia & 45 & 14 & 72 & Stepanauskas et al. (2002) \\
\hline Overall average $( \pm \mathrm{SE})$ & $28 \pm 2$ & & $30 \pm 4$ & \\
\hline \multicolumn{5}{|l|}{ (B) $\mathrm{DOC}$} \\
\hline \multicolumn{5}{|l|}{ United States } \\
\hline White Clay Creek & $144-772$ & NA & $21-34$ & Volk et al. (1997) \\
\hline Savannah River & $267-358$ & $35-58$ & $7-18$ & Moran et al. (1999) \\
\hline Ogeechee River & 317 & 35 & 7 & Moran et al. (1999) \\
\hline Altamaha River & $258-267$ & $35-58$ & $6-7$ & Moran et al. (1999) \\
\hline Satilla River & $275-2492$ & $35-98$ & $2-9$ & Moran et al. (1999) \\
\hline St. Marys River & 350 & 35 & 8 & Moran et al. (1999) \\
\hline York River & $438-867$ & $60-365$ & $8-63$ & Raymond \& Bauer $(2001 \mathrm{a}, \mathrm{b})$ \\
\hline \multicolumn{5}{|l|}{ Belgium } \\
\hline Forest River & 150 & 15 & 11 & Servais et al. (1987) \\
\hline Meuse River & $292-412$ & 15 & $19-33$ & Servais et al. (1987) \\
\hline Scheldt River & $650-1108$ & $15-28$ & $17-59$ & Servais et al. $(1987,1989)$ \\
\hline Rupel River & $625-942$ & 28 & $26-54$ & Servais et al. (1989) \\
\hline \multicolumn{5}{|l|}{ Other countries } \\
\hline Tamagawa River, Japan & 750 & 30 & 67 & Ogura (1975) \\
\hline Vistula River, Poland & $600-783$ & 90 & $23-36$ & Pempkowiak (1985) \\
\hline Rio Negro, Brazil & 801 & 3.5 & 3 & Amon \& Benner (1996) \\
\hline Rio Solimoes, Brazil & 378 & 2.9 & 7 & Amon \& Benner (1996) \\
\hline Overall average $( \pm S E)$ & $634 \pm 68$ & & $25 \pm 2$ & \\
\hline
\end{tabular}


gen-containing functional groups from DOM molecules and/or (2) bacteria could preferentially consume nitrogen-rich molecules in the DOM pool. Previous studies have also observed higher bacterial consumption of DON relative to DOC and have shown that the
2 elements have different fates in the bacterial community (Stepanauskas et al. 2000, Wiegner \& Seitzinger 2001, 2004). DON is often converted into bacterial biomass, while DOC is respired (Wiegner \& Seitzinger 2004). Bacteria have also been shown to grow

Table 6. Bioavailability of (A) DON and (B) DOC in non-point source runoff. Averages $( \pm$ SE) were calculated using the orignal data from the papers. NA: data not available

\begin{tabular}{|c|c|c|c|c|c|}
\hline $\begin{array}{l}\text { Non-point } \\
\text { source }\end{array}$ & Site & $\begin{array}{c}\text { DOM } \\
\text { conc. }(\mu \mathrm{M})\end{array}$ & $\begin{array}{l}\text { Experiment } \\
\text { length (d) }\end{array}$ & $\begin{array}{c}\text { DOM } \\
\text { used (\%) }\end{array}$ & Source \\
\hline \multicolumn{6}{|l|}{ (A) $\mathrm{DON}$} \\
\hline Wetlands & $\begin{array}{l}\text { Isgrannatorp, Sweden }^{\mathrm{a}} \\
\text { Vombe, Sweden }^{\mathrm{a}} \\
\text { Amböke, Sweden }^{\mathrm{a}} \\
\text { Cedar Bogs, USA } \\
\text { Average ( } \pm \text { SE) }\end{array}$ & $\begin{array}{c}176-180 \\
13-109 \\
16-32 \\
11-50 \\
\mathbf{7 4} \pm \mathbf{1 4}\end{array}$ & $\begin{array}{c}6-14 \\
6-14 \\
6-14 \\
4\end{array}$ & $\begin{array}{c}0-2 \\
0-2 \\
0-16 \\
0-65 \\
\mathbf{9} \pm \mathbf{4}\end{array}$ & $\begin{array}{l}\text { Stepanauskas et al. (1999a) } \\
\text { Stepanauskas et al. (1999a) } \\
\text { Stepanauskas et al. (1999a) } \\
\text { Wiegner \& Seitzinger (2004) }\end{array}$ \\
\hline \multirow[t]{2}{*}{ Forest } & $\begin{array}{l}\text { Bass River, USA } \\
\text { Hardwood-1, USA }\end{array}$ & $\begin{array}{c}4-8 \\
3-12\end{array}$ & $\begin{array}{l}10-12 \\
10-12\end{array}$ & $\begin{array}{c}28-44 \\
8-48\end{array}$ & $\begin{array}{l}\text { Seitzinger et al. (2002) } \\
\text { Seitzinger et al. (2002) }\end{array}$ \\
\hline & Hardwood-2, USA ${ }^{\mathrm{c}}$ & $15-20$ & $10-12$ & $\begin{array}{l}0-34 \\
\mathbf{2 4} \pm \mathbf{5}\end{array}$ & $\begin{array}{l}\text { Wiegner \& Seitzinger (2001), } \\
\text { Seitzinger et al. (2002) }\end{array}$ \\
\hline \multirow[t]{3}{*}{ Agriculture } & Swine Pasture, USA ${ }^{\mathrm{c}}$ & $45-127$ & $10-12$ & $21-47$ & $\begin{array}{l}\text { Wiegner \& Seitzinger (2001), } \\
\text { Seitzinger et al. (2002) }\end{array}$ \\
\hline & Equine Pasture, USA $^{c}$ & $47-203$ & $10-12$ & $12-46$ & $\begin{array}{l}\text { Wiegner \& Seitzinger (2001), } \\
\text { Seitzinger et al. (2002) }\end{array}$ \\
\hline & $\begin{array}{l}\text { Bovine Pasture, USA } \\
\text { Average }( \pm \mathrm{SE})\end{array}$ & $\begin{array}{l}119-260 \\
132 \pm 23\end{array}$ & $10-12$ & $\begin{array}{l}10-38 \\
29 \pm 4\end{array}$ & Seitzinger et al. (2002) \\
\hline Urban & $\begin{array}{l}\text { Mile Run Brook, USA } \\
\text { Lyell Brook, USA } \\
\text { Site G, USA } \\
\text { Average }( \pm \text { SE) }\end{array}$ & $\begin{array}{c}19-44 \\
60-164 \\
3-60 \\
\mathbf{6 1} \pm \mathbf{1 5}\end{array}$ & $\begin{array}{l}10-12 \\
10-12 \\
10-12\end{array}$ & $\begin{array}{l}51-73 \\
57-72 \\
42-59 \\
\mathbf{5 9} \pm \mathbf{4}\end{array}$ & $\begin{array}{l}\text { Seitzinger et al. (2002) } \\
\text { Seitzinger et al. (2002) } \\
\text { Seitzinger et al. (2002) }\end{array}$ \\
\hline \multicolumn{6}{|l|}{ (B) DOC } \\
\hline Wetlands & $\begin{array}{l}\text { Talladega Wetland Ecosystem, USA } \\
\text { Shibakusa-Daira Mountain, Japan } \\
\text { Average }( \pm \text { SE) }\end{array}$ & $\begin{array}{c}209-267 \\
833-916 \\
\mathbf{4 2 2} \pm \mathbf{1 1 8}\end{array}$ & $\begin{array}{c}1 \\
90\end{array}$ & $\begin{array}{l}24-69 \\
16-20 \\
\mathbf{3 7} \pm \mathbf{8}\end{array}$ & $\begin{array}{l}\text { Mann \& Wetzel (1995) } \\
\text { Satoh \& Abe (1987) }\end{array}$ \\
\hline Forest & $\begin{array}{l}\text { Coweeta Hydrological Laboratory, USA } \\
\text { Lindar Forest, France }^{\mathrm{d}} \\
\text { Hardwood Forest, USA }^{\mathrm{f}} \\
\text { Harvard Forest-Pine No N Site, USA } \\
\text { Harvard Forest-Pine Chronic N Site, USA } \\
\text { Harvard Forest-Hardwood No N Site, USA } \\
\text { Harvard Forest-Hardwood Chronic N Site, USA } \\
\text { Hardwood Forest Stream, USA } \\
\text { Average }( \pm \text { SE) }\end{array}$ & $\begin{array}{c}500^{\mathrm{h}} \\
625-1192 \\
1180-4250 \\
833^{\mathrm{h}} \\
833^{\mathrm{h}} \\
833^{\mathrm{h}} \\
833^{\mathrm{h}} \\
346 \\
\mathbf{1 6 5 0}^{\mathrm{i}} \pm \mathbf{4 2 4}\end{array}$ & $\begin{array}{c}134 \\
14 \\
14 \\
\text { NA } \\
\text { NA } \\
\text { NA } \\
\text { NA } \\
10\end{array}$ & $\begin{array}{c}14-33 \\
4-40 \\
12-21 \\
15 \\
43 \\
12 \\
44 \\
6 \\
\mathbf{2 1} \pm \mathbf{3}\end{array}$ & $\begin{array}{l}\text { Qualls \& Haines (1992) } \\
\text { Boissier \& Fontvieille (1993) } \\
\text { Boyer \& Groffman (1996) } \\
\text { Yano et al. (1998) } \\
\text { Yano et al. (1998) } \\
\text { Yano et al. (1998) } \\
\text { Yano et al. (1998) } \\
\text { Wiegner \& Seitzinger (2001) }\end{array}$ \\
\hline Agriculture & $\begin{array}{l}\text { Swine Pasture, USA } \\
\text { Equine Pasture, USA } \\
\text { Soybean/Ryegrass-Saone, France } \\
\text { Maize Field, USA }{ }^{\mathrm{f}} \\
\text { Average }( \pm \mathbf{S E})\end{array}$ & $\begin{array}{c}642 \\
487 \\
\text { NA } \\
1180-8264 \\
\mathbf{4 0 4 5} \pm \mathbf{1 6 2 7}\end{array}$ & $\begin{array}{l}10 \\
10 \\
28 \\
14\end{array}$ & $\begin{array}{c}9 \\
14 \\
19-22 \\
12-27 \\
\mathbf{1 6} \pm \mathbf{2}\end{array}$ & $\begin{array}{l}\text { Wiegner \& Seitzinger (2001) } \\
\text { Wiegner \& Seitzinger (2001) } \\
\text { Nelson et al. (1994) } \\
\text { Boyer \& Groffman (1996) }\end{array}$ \\
\hline $\begin{array}{l}{ }^{a} \text { Bioavailabil } \\
{ }^{b} \text { Bioavailabi } \\
\text { "Bioavailabi } \\
\text { dBioavailabi } \\
\text { eBioavailabi } \\
{ }^{\text {f }} \text { Bioavailabi } \\
\text { gBioreactors } \\
\text { hDOC conce }\end{array}$ & $\begin{array}{l}\text { of wetland DON to freshwater and estuarine heter } \\
\text { of wetland DON from pristine and polluted cedar } \\
\text { of DON to freshwater and estuarine heterotrophic } \\
\text { of DOC from forest stream and different soil horiz } \\
\text { of DOC from mottled brown and podzolic pseudo } \\
\text { of DOC from } 0.1 \text { to } 0.7 \mathrm{~m} \text { depth in soil } \\
\text { re used to measure DOC bioavailability } \\
\text { ation in experiment, not in situ value }\end{array}$ & $\begin{array}{l}\text { rotrophic bac } \\
\text { bogs } \\
\text { bacteria } \\
\text { ons } \\
\text { gley soils }\end{array}$ & teria & & \\
\hline
\end{tabular}


more efficiently on nitrogen-rich DOM (Wiegner \& Seitzinger 2004).

Our results in conjunction with previous studies have implications for the quantity and quality of DOM exported from rivers to estuaries and the role of this material in freshwater and estuarine food webs. First, the preferential consumption of nitrogen relative to carbon may result in export of nitrogen-deplete allochthonous DOM from rivers to estuaries. This can affect both the amount of DON and DOC exported, as well as the quality of the material (DOC:DON). Second, the consumption of DON and its conversion into bacterial biomass may be an important pathway by which nitrogen is transferred from the microbial food web to higher trophic levels, whereas this pathway may be less important for transferring carbon to higher trophic levels.

\section{$\mathrm{N}$ sources to bacteria}

DON is an important nitrogen source to heterotrophic bacteria in rivers (Carlsson et al. 1993, 1999, Seitzinger \& Sanders 1997, Stepanauskas et al. 2000, 2002). In our experiment, DON comprised $43 \%( \pm 6)$ of the TDN consumed by bacteria (Fig. 3). Urea may have accounted for up to $100 \%$ of the DON utilized in some rivers (Tables $2 \& 3$ ). Increasingly, urea is recognized to contribute significantly to the total DON pool and to the fraction of bioavailable DON in many riverine, estuarine, and coastal systems (Glibert et al. 2006). Our data show that DON was consumed by bacteria even when DIN was available (Tables 3 \& 4). In other freshwater and estuarine systems, DON has been shown to comprise 70 to $100 \%$ of the TDN consumed by bacteria (calculated from Seitzinger \& Sanders 1997, 1999, Jørgensen et al. 1999, Kerner \& Spitzy 2001, Wiegner \& Seitzinger 2001). Recent studies have also shown that DON can support 5 times more bacterial carbon production per micromole of nitrogen than DIN (Seitzinger et al. 2002). Our results in conjunction with previous studies suggest that DON consumption may be more advantageous for bacteria than consuming DIN, because it also provides carbon (energy).

DIN comprised the remainder $(57 \%)$ of the TDN consumed by bacteria in our study (calculated from Tables $3 \& 4$ ). $\mathrm{NH}_{4}{ }^{+}$was the primary form of DIN used in most rivers, except in the Forest $17 \mathrm{a}$ and Hudson Rivers, where more $\mathrm{NO}_{3}{ }^{-}+\mathrm{NO}_{2}^{-}$was consumed (Table 4). The preferential consumption of $\mathrm{NH}_{4}{ }^{+}$was not surprising given that its assimilation requires less energy than $\mathrm{NO}_{3}{ }^{-}+\mathrm{NO}_{2}{ }^{-}$. However, it was surprising that DON and DIN were consumed simultaneously given that the ratio of DOC:DON con- sumed in most of the rivers was similar to or lower (averaging 5:1; calculated from Table 3) than the average C:N ratio of a bacterial cell ( 5:1; Goldman et al. 1987, Fagerbakke et al. 1996, Fukuda et al. 1998). A paradigm in aquatic ecology is that bacteria consume DOM and DIN simultaneously when the $\mathrm{C}: \mathrm{N}$ ratio of the DOM they are consuming is higher than their cellular C:N ratio (Goldman et al. 1987, Goldman \& Dennett 1991). Our results in conjunction with previous studies suggest that this paradigm may be more complex than previously assumed (Goldman et al. 1987, Goldman \& Dennett 1991). Concurrent $\mathrm{NH}_{4}{ }^{+}$and amino acid uptake has been observed to occur as long as a readily bioavailable carbon source is available (Goldman \& Dennet 1991). Although DOC consumption in our experiment was low compared to other riverine DOM bioavailability studies (Table 5), a sufficient amount of readily bioavailable carbon must have been available to support the simultaneous uptake of DIN and DON by bacteria.

\section{SUMMARY}

Studies on the quality of coastal waters have long ignored inputs of DOM from rivers because it was assumed that the nitrogen and carbon components from this pool were biologically unavailable. Our study demonstrates that DOM is an important nutrient and energy source to heterotrophic bacteria. In particular, the nitrogen component of the DOM pool was bioavailable. Across 7 of the rivers examined in this study, $23 \%$ $( \pm 5)$ of the DON was bioavailable, which comprised $43 \%( \pm 6)$ of the TDN consumed by bacteria. These results demonstrate that DON is an important nitrogen source to bacteria and that a significant fraction of the pool is bioavailable within days. Summer may be a particularly important time for bioavailable DON transport to estuaries, even though river discharge and DON fluxes are low. Previous studies have found that riverine DON bioavailability is typically higher in the summer than during the winter (Stepanauskas et al. 1999, 2002), suggesting that its impact on the microbial community and contribution to eutrophication may be greater during this period. Our results in conjunction with previous studies demonstrate that DON cycles faster and supports more bacterial production than DOC (Wiegner \& Seitzinger 2004). Given these findings, DON needs to be incorporated into coastal nitrogen loading budgets. Currently, most of these budgets are based on riverine DIN inputs (i.e. Peierls et al. 1991). To make these budgets more accurate with regards to bioavailable nitrogen entering coastal waters, more spatial and temporal riverine DON bioavailability data are needed. 
Acknowledgements. E. Haramoto, R. Styles, R. Lauck, M. Calisto, J. Pierce, E. Koorie, and M. Sanderson assisted with laboratory and field work. J. LaRoche supplied water from the Peconic River. J. Fischer and R. Zampella supplied watershed basin information for the Delaware and East Bass Branch Rivers. C. Dow calculated the drainage area for Forest 17a. T. Komada, C. Reimers, K. Rowley, and O. Schofield provided thoughtful comments that helped improve this manuscript. This research is the result of work funded by NOAA Office of Sea Grant and Extramural programs, US Department of Commerce, under Grant No. R/D-9808 (Publication No. NJSG-01466) to T.N.W. and S.P.S., Maryland Sea Grant R/P-41 to P.M.G., and Georgia Sea Grant R/WQ-10 to D.A.B. This is Contribution Number 3964 from the University of Maryland Center for Environmental Science and VIMS Contribution 2738 from the Virginia Institute of Marine Science, College of William and Mary. The US government is authorized to produce and distribute reprints for governmental purposes notwithstanding any copyright notation that may appear hereon.

\section{LITERATURE CITED}

Aitkenhead-Peterson JA, McDowell WH, Neff JC (2003) Sources, production, and regulation of allochthonous dissolved organic matter inputs to surface waters. In: Findlay SEG, Sinsabaugh RL (eds) Aquatic ecosystems: interactivity of dissolved organic matter. Academic Press, New York, p 25-70

Amon RMW, Benner R (1996) Bacterial utilization of different size classes of dissolved organic matter. Limnol Oceanogr 41:41-51

Asbury CE, Oaksford ET (1997) A comparison of drainage basin nutrient inputs with instream nutrient loads for seven rivers in Georgia and Florida, 1986-90. WaterResources Investigations Report 97-4006, US Geological Survey, Tallahassee

Aufdenkampe AK, Hedges JI, Richey JE, Krusche AV, Llerena CA (2001) Sorptive fractionation of dissolved organic nitrogen and amino acids onto fine sediments within the Amazon Basin. Limnol Oceanogr 46:1921-1935

Boissier JM, Fontvieille D (1993) Biodegradable dissolved organic carbon in seepage waters from two forest soils. Soil Biol Biochem 25:1257-1261

Boyer JN, Groffman PM (1996) Bioavailability of water extractable organic carbon fractions in forest and agricultural soil profiles. Soil Biol Biochem 28:783-790

Boyer EW, Hornberger GM, Bencala KE, McKnight D (1996) Overview of a simple model describing variation of dissolved organic carbon in an upland catchment. Ecol Model 86:183-188

Bronk DA, Glibert PM (1993) Application of a ${ }^{15} \mathrm{~N}$ tracer method to the study of dissolved organic nitrogen uptake during spring and summer in Chesapeake Bay. Mar Biol 115:501-508

Carlsson P, Segatto AZ, Granéli E (1993) Nitrogen bound to humic matter of terrestrial origin-a nitrogen pool for coastal phytoplankton? Mar Ecol Prog Ser 97:105-116

Carlsson P, Granéli E, Segatto AZ (1999) Cycling of biologically available nitrogen in riverine humic substances between marine bacteria, a heterotrophic nanoflagellate and a photosynthetic dinoflagellate. Aquat Microb Ecol 18:23-36

del Giorgio PA, Davis J (2003) Patterns in dissolved organic matter lability and consumption across aquatic ecosystems. In: Findlay SEG, Sinsabaugh RL (eds) Aquatic ecosystems: interactivity of dissolved organic matter. Academic Press, New York, p 399-424

Fagerbakke KM, Heldal M, Norland S (1996) Content of carbon, nitrogen, oxygen, sulfur, and phosphorus in native aquatic and cultured bacteria. Aquat Microb Ecol 10: $15-27$

Findlay S, Sinsabaugh RL (1999) Unravelling the sources and bioavailability of dissolved organic matter in lotic aquatic ecosystems. Mar Freshw Res 50:781-790

Findlay S, Quinn JM, Hickey CW, Burrell G, Downes M (2001) Effects of land use and riparian flowpath on delivery of dissolved organic carbon to streams. Limnol Oceanogr 46:345-355

Fukuda R, Ogawa H, Nagata T, Koike I (1998) Direct determination of carbon and nitrogen contents of natural bacterial assemblages in marine environments. Appl Environ Microbiol 64:3352-3358

Glibert PM, Magnien R, Lomas MW, Alexander J, Fan C, Haramoto E, Trice M, Kana TM (2001) Harmful algal blooms in the Chesapeake and coastal bays of Maryland, USA: comparison of 1997, 1998, and 1999 events. Estuaries 24:875-883

Glibert PM, Harrison J, Heil C, Seitzinger S (2006) Escalating worldwide use of urea - a global change contributing to coastal eutrophication. Biogeochemistry 77:441-463

Goldman JC, Dennett MR (1991) Ammonium regeneration and carbon utilization by marine bacteria grown on mixed substrates. Mar Biol 109:369-378

Goldman JC, Caron DA, Dennett MR (1987) Regulation of gross growth efficiency and ammonium regeneration in bacteria by substrate C:N ratio. Limnol Oceanogr 32: 1239-1252

Hornberger GM, Bencala KE, McKnight DM (1994) Hydrological controls on dissolved organic carbon during snowmelt in the Snake River near Montezuma, Colorado. Biogeochemistry 25:147-165

Howarth RW, Fruci JR, Sherman D (1991) Inputs of sediment and carbon to an estuarine ecosystem: influence of land use. Ecol Appl 1:27-39

Howarth RW, Billen G, Swaney D, Townsend A and 11 others (1996) Regional nitrogen budgets and riverine $N$ \& $P$ fluxes for the drainages to the North Atlantic Ocean: natural and human influences. Biogeochemistry 35:75-139

Jørgensen NOG, Tranvik LJ, Berg GM (1999) Occurrence and bacterial cycling of dissolved nitrogen in the Gulf of Riga, the Baltic Sea. Mar Ecol Prog Ser 191:1-18

Kaplan LA, Newbold JD (1993) Biogeochemistry of dissolved organic carbon entering streams. In: Ford TE (ed) Aquatic microbiology: an ecological approach. Blackwell Scientific Publications, Boston, MA, p 139-165

Kerner M, Spitzy A (2001) Nitrate regeneration coupled to degradation of different size fractions of DON by the picoplankton in the Elbe Estuary. Microb Ecol 41:69-81

Kerner M, Hohenberg H, Ertl S, Reckermann M, Spitzy A (2003) Self-organization of dissolved organic matter into micelle-like microparticles in river water. Nature 422: $150-154$

Mann CJ, Wetzel RG (1995) Dissolved organic carbon and its utilization in a riverine wetland ecosystem. Biogeochemistry 31:99-120

Mantoura RFC, Woodward EMS (1983) Conservative behaviour of riverine dissolved organic carbon in the Severn Estuary: chemical and geochemical implications. Geochim Cosmochim Acta 47:1293-1309

Moran MA, Sheldon WM, Sheldon JE (1999) Biodegradation of riverine dissolved organic carbon in five estuaries of the southeastern United States. Estuaries 22:55-64 
Nelson PN, Dictor MC, Soulas G (1994) Availability of organic carbon in soluble and particle-size fractions from a soil profile. Soil Biol Biochem 26:1549-1555

Ogura N (1975) Further studies on decomposition of dissolved organic matter in coastal seawater. Mar Biol 31:101-111

Paerl HW, Pinckney JL, Fear JM, Peierls BL (1998) Ecosystem responses to internal and watershed organic matter loading: consequences for hypoxia in the eutrophying Neuse River Estuary, North Carolina, USA. Mar Ecol Prog Ser 166:17-25

Palmer SM, Hope D, Billett MF, Dawson JJC, Bryant CL (2001) Sources of organic and inorganic carbon in a headwater stream: evidence from carbon isotope studies. Biogeochemistry 52:321-338

Peierls BL, Caraco NF, Pace ML, Cole JJ (1991) Human influence on river nitrogen. Nature 350:386-387

Pempkowiak J (1985) The input of biochemically labile and resistant organic matter to the Baltic Sea from the Vistula River. Mitt Geol-Paläont Inst Univ Hambg 58:345-350

Potvin C, Roff DA (1993) Distribution-free and robust statistical methods: viable alternatives to parametric statistics? Ecology 74:1617-1628

Price NM, Harrison PJ (1987) Comparison of methods for the analysis of dissolved urea in seawater. Mar Biol 94: 307-317

Qualls RG, Haines BL (1992) Biodegradability of dissolved organic matter in forest throughfall, soil solution, and stream water. Soil Sci Soc Am J 56:578-586

Raymond PA, Bauer JE (2001a) Riverine export of aged terrestrial organic matter to the North Atlantic Ocean. Nature 409:497-500

Raymond PA, Bauer JE (2001b) Use of ${ }^{14} \mathrm{C}$ and ${ }^{13} \mathrm{C}$ natural abundances for evaluating riverine, estuarine, and coastal DOC and POC sources and cycling: a review and synthesis. Org Geochem 32:469-485

Satoh Y, Abe H (1987) Dissolved organic matter in colored water from mountain bog pools in Japan. II. Biological decomposability. Arch Hydrobiol 111:25-35

Schlesinger WH, Melack JM (1981) Transport of organic carbon in the world's rivers. Tellus 33:172-187

See JH, Bronk DA, Lewitus AJ (2006) Uptake of Spartinaderived humic nitrogen by estuarine phytoplankton in non-axenic and axenic culture. Limnol Oceanogr 51(5):(in press)

Seitzinger SP, Sanders RW (1997) Contribution of dissolved organic nitrogen from rivers to estuarine eutrophication. Mar Ecol Prog Ser 159:1-12

Seitzinger SP, Sanders RW (1999) Atmospheric inputs of dissolved organic nitrogen stimulate estuarine bacteria and phytoplankton. Limnol Oceanogr 44:721-730

Seitzinger SP, Sanders RW, Styles R (2002) Bioavailability of DON from natural and anthropogenic sources to estuarine plankton. Limnol Oceanogr 47:353-366

Seitzinger SP, Hartnett H, Lauck R, Mazurek M, Minegishi T, Spyres G, Styles R (2005) Molecular-level chemical characterization and bioavailability of dissolved organic mat-

Editorial responsibility: Paul A. del Giorgio,

Montréal, Quebec, Canada ter in stream water using electrospray-ionization mass spectrometry. Limnol Oceanogr 50:1-12

Servais P, Billen G, Hascoët MC (1987) Determination of the biodegradable fraction of dissolved organic matter in waters. Water Res 21:445-450

Servais P, Anzil A, Ventresque C (1989) Simple method for determination of biodegradable dissolved organic carbon in water. Appl Environ Microbiol 55:2732-2734

Sharp JH, Benner R, Bennett L, Carlson CA, Dow R, Fitzwater SE (1993) Re-evaluation of high temperature combustion and chemical oxidation measurements of dissolved organic carbon in seawater. Limnol Oceanogr 38: $1774-1782$

Sobzcak WV, Findlay S (2002) Variation in bioavailability of dissolved organic carbon among stream hyporheic flowpaths. Ecology 83:3194-3209

Stepanauskas R, Leonardson L, Tranvik LJ (1999a) Bioavailability of wetland-derived DON to freshwater and marine bacterioplankton. Limnol Oceanogr 44:1477-1485

Stepanauskas R, Edling H, Tranvik LJ (1999b) Differential dissolved organic nitrogen availability and bacterial aminopeptidase activity in limnic and marine waters. Microb Ecol 38:264-272

Stepanauskas R, Laudon H, Jørgensen NOG (2000) High DON bioavailability in boreal streams during a spring flood. Limnol Oceanogr 45:1298-1307

Stepanauskas R, Jørgensen NOG, Eigaard OR, Zvikas A, Tranvik LJ, Leonardson L (2002) Summer inputs of riverine nutrients to the Baltic Sea: bioavailability and eutrophication relevance. Ecol Monogr 72:579-597

Sun L, Perdue EM, Meyer JL, Weis J (1997) Use of elemental composition to predict bioavailability of dissolved organic matter in a Georgia river. Limnol Oceanogr 42:714-721

Thurman EM (1985) Organic geochemistry of natural waters. Martinus Nijhoff/W. Junk Publishers, Dordrecht

Valderrama JC (1981) The simultaneous analysis of total nitrogen and phosphorus in natural waters. Mar Chem 10: 109-122

Volk CJ, Volk CB, Kaplan LA (1997) Chemical composition of biodegradable dissolved organic matter in streamwater. Limnol Oceanogr 42:39-44

Wiegner TN, Seitzinger SP (2001) Photochemical and microbial degradation of external dissolved organic matter inputs to rivers. Aquat Microb Ecol 24:27-40

Wiegner TN, Seitzinger SP (2004) Seasonal bioavailability of dissolved organic carbon and nitrogen from pristine and polluted freshwater wetlands. Limnol Oceanogr 49: $1703-1712$

Wikner J, Cuadros R, Jansson M (1999) Differences in consumption of allochthonous DOC under limnic and estuarine conditions in a watershed. Aquat Microb Ecol 17: $289-299$

Yano Y, McDowell WH, Kinner NE (1998) Quantification of biodegradable dissolved organic carbon in soil solution with flow-through bioreactors. Soil Sci Soc Am J 62: 1556-1564

Submitted: November 11, 2005; Accepted: March 22, 2006

Proofs received from author(s): July 11, 2006 